\title{
Personality and Legal Culture
}

\author{
A.H. Angelo*
}

The interaction of Maori law and the European based state law of New Zealand has given rise to much discussion and political debate. The contemporary focus has been primarily on the Treaty of Waitangi and the work of the Waitangi Tribunal. Public interest has been attracted by the property aspects of Treaty claims and by their justness, but there has been less public interest in the Maori cultural aspects of claims. In particular the cultural importance of some claims has been masked by concerns about the resource value involved. This paper seeks to redirect attention to an aspect of the Maori cultural meaning involved where claims concern taonga, and it suggests further that coherence of claims settlements may in some cases be advanced by reference to the concept of personality.

Discussion in recent years in New Zealand has focused much on bi-culturalism and, in particular, on the recognition of the quality and status of Maori concepts and values within the European culturally dominated system of government which operates in New Zealand. These discussions have stemmed mainly from the interpretation of the simple but evocative articles of the Treaty of Waitangi of 1840 .

The Waitangi Tribunal began its work in $1975^{1}$, and since then it has progressively raised the New Zealand consciousness of the nature and importance of the different cultural values that exist within New Zealand society. The judiciary, the legislature, andurn built on the developing cultural perspectives ${ }^{2}$.

One of the matters that has been considered in the context of article 2 of the Treaty of Waitangi is the concept of taonga. ${ }^{3}$ It is the purpose of this paper to explore some of the issues involved in relation to taonga to see whether, in the light of the available English

* Professor of Law, Victoria University of Wellington; with the research assistance of Carla Angelo, BA.

1 Established by the Treaty of Waitangi Act 1975.

2 See eg Maori Council Case v Attorney-General [1987] 1 NZLR 641, Maori Language Act 1987, and the deed of settlement between Tainui and the Crown which is enshrined in the Waikato Raupatu Claims Settlement Act 1995.

3 The discussion has reached the point where taonga is now part of standard New Zealand English with the particular meaning of "valued possession". 
language data, a possible bridge between the Maori legal system and the Common Law legal system can be built using the notion of personality. The identity and spiritual aspects of significant taonga call to mind notions of personality within European legal culture. The view presented here is (1) that the Common Law would have much greater flexibility for dealing with taonga if some taonga had legal personality, because this characteristic gives the subject rights and duties under the Common Law, and (2) that this legal perception is not incompatible with the nature of taonga in the Maori legal system. Having legal personality would mean that a taonga would itself be involved in any decisions made about it, it would not be a commodity and that it woud be treated as a single entity rather than a collection of related assets.

The first part of this paper is concerned with specific features of taonga, and the second part with the European legal notions of personality. The third part explores the possibility that the attribution of Common Law legal personality to a taonga may be an appropriate manner at Common Law of allocating to taonga some of the qualities which taonga possess in Maori law and thereby provide the possibility of greater similarity of treatment of taonga in the two legal cultures.

\section{Taonga}

\section{Definition}

Taonga is a word with many meanings. It would appear that it can be translated into English in three main ways. First ${ }^{4}$ and in its most general form, taonga can be translated as "property". Second ${ }^{5}$, "anything highly prized" can be taonga; taonga is often translated as treasures or prized possessions. ${ }^{6}$

A third ${ }^{7}$ important aspect of this word is that taonga are not only property or treasures, but that a taonga can also be "a possession of influence, sometimes mental". Some authors ${ }^{8}$ have stated that taonga have a spirit and an influence over people though not all taonga

4 H Williams A Dictionary of the Maori Language (7ed, Government Print, New Zealand, 1992, p 381).

5 See Williams above, $\mathrm{n} 4$.

6 Eg H Mead “The Nature of Taonga" (1990) Taonga Maori Conference Proceedings; Waitangi Tribunal Mohaka River Report (Brooker \& Friend Ltd, Wellington, 1992).

7 E Tregear The Maori-Polynesian Comparative Dictionary (Whitcombe \& Tombs, Christchurch, 1897) p 468.

$8 \quad$ Eg see Mead above n6; M Mauss The Gift (Cohen \& West Ltd, London, 1970) 9. 
have the same amount of spiritual power. ${ }^{9}$ This idea of a possession of influence can also be interpreted as something that "allow[s] one to gain the influence he desires"10.

The Treaty of Waitangi ${ }^{11}$ states that Maori are guaranteed full rights of ownership "of their Lands and Estates Forests Fisheries and other properties". These other properties are "o ratou taonga katoa" in the Maori version. This phrase can be translated in various ways: Mead" 12 translates it as "all their valued possessions and customs" because "o ratou taonga katoa" is said to cover both tangible and intangible things; the Waitangi Tribunal in the Kaituna River Report accepted that the phrase meant "all things highly prized"13; another translation renders the phrase as a guarantee of "full rights of ownership of their lands, forests, fisheries and other prized possessions". ${ }^{14}$ The lands, forests, rivers and fisheries of article 2 of the Treaty are themselves taonga.

In the main, contemporary understanding suggests that taonga are - physical objects of artistic or cultural value ${ }^{15}$, forests, rivers ${ }^{16}$, language ${ }^{17}$, customs, traditions, rituals, songs ${ }^{18}$, land, trees, weapons, and perhaps even people ${ }^{19}$. Taonga can be identified because of their special relationship to people, because of their links to, and the length of, their history and generally because of their value to the culture.

\section{Creation and Destruction}

It is difficult to describe exactly how something becomes taonga. For example, an object may be regarded as taonga if it belongs to a person who possesses great mana. Objects which are seen to contain history are also given the title taonga. Thus the prestige of a

9 See Mead above n6, 166-167.

10 Eg possessing a taonga like money/wealth may allow someone to influence others ("He tukemata ano to te taonga"), H Mead Nga Pepeha a Nga Tupuna (Dep. Maori Studies, VUW, 1994, v.2, p88).

11 See the Treaty of Waitangi Act 1975, Sched 1. The relevant article is art. 2.

12 Report of the Waitangi Tribunal on the Te Reo Maori Claim (Wai 11) (Brookers, Wellington, 1993) 20.

13 Report of the Waitangi Tribunal on the Kaituna River Claim ((Wai 4) (Government Printing Office, Wellington, 1989) 13) as reported in the Report on the Te Reo Maori (above n12).

14 C Orange The Treaty of Waitangi (Department of Internal Affairs, Wellington, 1992) 1-2.

15 See Taonga Maori (Australian Museum, Sydney, 1989).

16 See Mohaka River Report above n6, 78.

17 Waitangi Tribunal Te Reo Report (Brookers, Wellington, 1986).

18 A Kaeppler "Taonga Maori and the Evolution of the Representation of 'other'" (1990) Taonga Maori Conference Proceedings, p12.

19 See B Briggs Maori Marriage (Reed, New Zealand, 1960) 36-39; H Mead Nga Pepeha a Nga Tupuna (Department of Maori Studies, Victoria University of Wellington, 1994, vol. 3 p159. 
taonga strengthens with its age, the amount of history it possesses, and through its association with people of great mana.

In the case of art objects there is a tapu that surrounds the creation of art because art is seen as a way in which the Gods speak to Maori ${ }^{20}$. Mead ${ }^{21}$ states that "Providing korero is an expected part of the process of creating taonga".22 "Whakairo is the process of transforming something natural into something cultural called a taonga" ${ }^{\prime 23}$. The taonga is imbued with the spirit of the creator.

In the case of land, rivers, forests and other environmental or physical entities, they appear to obtain the title of taonga if they are of historical importance to the tribe, and are seen as important to the survival of humans. ${ }^{24}$ The responsibility Maori feel to the environment and the special spiritual link that Maori have to the land may also contribute to the designation as taonga. It is the history and the genealogical link that Maori have with the land through Tane that makes the land taonga ${ }^{25}$.

If an art object is destroyed the taonga itself is destroyed. On a different level taonga can lose status if their historical content is lost. Because Maori history was oral rather than written, if a taonga was taken away from the tribe or removed from New Zealand and no record was maintained, the history of the taonga was lost. Thus, the taonga, while still a taonga, was no longer as prized as it had been.

\section{Identification}

In some cases taonga are relatively easy to identify. However, in the case of geographical features such as land or rivers the exact boundaries of the taonga may be determined differently by Maori law than by the common law system. The area in which a tribe lives is seen as taonga by that tribe (it is the area with which they identify or with

20 See Taonga Maori above n 15, 45.

21 See Mead above n6, 165-166.

22 See Mead above n6, 166. Korero here refers to the stories and explanations given in relation to the creation of art works.

23 See Mead above n6, 166.

24 See Taonga Maori above n15, 36 .

25 For the legends of the creation of heaven and earth and the creation of the first female in human form by Tane, see eg M Orbell The Illustrated Encyclopedia of Maori Myth and Legend (CUP: Christchurch, 1995) 179, and A W Reed Maori Myth and Legend (Reed, Wellington, 1983). The common use of the word whenua for both land and afterbirth should also be noted. "The word whenua is the Maori word for placenta, ..., whenua is also the term used for land, the body of Papatuanuku (mother Earth) ... when a child was born the placenta was buried in a special place where people would not walk over or discover it. This place became spiritual and important to that person". See Taonga Maori above n15, 40. 
which they are identified). ${ }^{26}$ Maori have spiritual links to the land and regard themselves are guardians of it. All land, including the plants that grow on it, and all the river (including the water of the river, the fish in the river, the river bed) are taonga ${ }^{27}$ - "a whole and indivisible entity, not separated into bed, banks, and waters" 28 .

\section{Characteristics of "prized possessions"}

A taonga, be it an art object or a geographical feature, can have several main characteristics all or some of which may be apparent at any given time. Mead ${ }^{29}$ discusses the details of the characteristics. For example, taonga are seen to represent ancestors, to be symbols or identifiers of iwi, and to possess mana or prestige. Many of these characteristics are linked to one another. For instance the characteristic of representing ancestors leads to the taonga gathering mana.

\section{(i) Passing from generation to generation}

The Mohaka River Report ${ }^{30}$ states that an essential characteristic of a taonga is that it is passed down from generation to generation. From this flow other characteristics, such as the gaining in strength of the taonga as it is passed down. The responsibility to care for the taonga is also passed down and its relationship to humans can develop in this way. Taonga are "part of a line of descent which stretches from the most distant past into the most distant future"31. Mead states that "this means that the living descendants are trustees of the taonga by right of whakapapa or genealogical descent $t^{\prime \prime 2}$.

\section{(ii) Taonga as tellers of history}

Taonga play an important part in Maori history by enabling that history to be remembered, told, and passed on. For example, carvings and art objects often contain symbols that tell a story and also, in the case of the environment, history was told in relation to, for instance, what happened on that mountain ${ }^{33}$.

26 These issues are discussed in the Kaituna River Claim above n 13, 9.

27 See Mohaka River Report above n 6, 11.

28 Mohaka River Report above $n$ 6, 36. This synopsis of the Maori view of the river is cited by the Court of Appeal in Te Runanganui o Te Ika Whenua Inc Society v Attorney-General [1994] 2 NZLR 20, 26.

29 See Mead above $n 6$.

30 See Mohaka River Report above n 6. 10.

31 See Taonga Maori above n 15, 51.

32 See Mead above n 6, 166.

33 "Tribal history is written over the hills and valleys, the rivers, streams and lakes, and upon the cliffs, rocks and shores". Taonga Maori above n 15, 38. 


\section{(iii) Taonga have strength}

"The more generations involved in the handing down the greater the mana (prestige) of the object". ${ }^{34}$ Taonga gather strength as they pass from one generation to the next. "Taonga carry with them the mana of the old people" 35 . According to Kaeppler ${ }^{36}$ "taonga derive their primary value from their whakapapa and specific histories that connect them with particular ancestors".

\section{(iv) Representer of ancestors}

In some cases, taonga are seen to represent ancestors. ${ }^{37}$ They are seen to provide a remembrance of those to whom they once belonged (ie remind other generations of their ancestors) and people may shed tears over taonga in remembrance of their ancestors ${ }^{38}$.

\section{(v) Identifier of the tribe}

A taonga may symbolise or be used as an identifier for a tribe ${ }^{39}$, as is the case with the Mohaka River, which is seen as an identifier by the Ngati Pahauwera. They feel that "without the heritage of the river we are nobody"40 and that the tribe's "mana is derived from the river"41. The taonga is seen to give Maori their identity, validate existence, order chaos, and help guide their destiny ${ }^{42}$.

34 See Mead above $n$ 6, 166.

35 See Taonga Maori above n 15, 51.

36 See Kaeppler above n 18, 15.

37 See Taonga Maori above n 15, 45.

38 See Taonga Maori above n 15, 45.

39 See Taonga Maori above n 15, 45.

40 Mohaka River Report, above n6, 19.

41 See Mohaka River Report above n 6, 10 and 18-21.

42 See Taonga Maori above n 15, 17. 


\section{(vi) Taonga and Personality}

A taonga may have a personality. ${ }^{43}$ If a taonga is given a name, and thus its own personal identity, it gains more prestige $\mathrm{H}^{44}$. It is also to be noted that objects such as spears and meeting houses are created in the human form. That is to say a spear has a head and a body, as does a meeting house. Entry into a meeting house is replete with symbolism, part of which includes entering the body of the past and being reintegrated with it.

Taonga are treated with great respect ${ }^{45}$; taonga command respect ${ }^{46}$ and there is a need "to keep the taonga warm". ${ }^{47}$ If, for instance, art objects have been taken from a tribe and are later returned there may be a welcoming ceremony, much like the ceremony a long lost child might receive when it returns home. The fact that taonga may represent ancestors also adds to their personality. Taonga may be embraced or hugged and people may speak to them as if they were human ${ }^{48}$. Mauss ${ }^{49}$ comments that the taonga or its spirit is a kind of individual.

\section{(vii) Spirit and spirituality of taonga}

Taonga have a spirit (hau) or spiritual power. Mauss suggested further that this power has magical and religious elements. ${ }^{50} \mathrm{He}$ quoted a proverb ${ }^{51}$ which states that taonga may have the power to destroy those who receive them as gifts if there is a breach of reciprocity. This is corroborated by Best ${ }^{52}$ who reported that if someone received a gift (taonga) and later sold that taonga to someone else, that person had to give the money or thing for which

43 It is interesting to note that the Declaration of Independence of the Independent Tribes of New Zealand of 1835, the independent state Te Whenua Rangatira "was personified as a rangatira, given the qualities of a traditional kinship leader" (H Levine and M Henare "Mana Maori Motuhake: Maori Self-Determination" (1994) 35 Pacific Viewpoint 193). See also M Henare "There is no Tribal History, only Maori History" paper presented to 1994 NZ Historical Association Conference.

44 Eg a greenstone weapon named Tuhiwai is housed in the Museum of New Zealand.

45 See Taonga Maori above n 15, 62.

46 See Mohaka River Report above n 6, 13.

47 See Kaeppler above n 18, 18.

48 See Mead above n 6, 166.

49 See Mauss above n 8, 8-11.

50 See Mauss above n 8, 8-11.

51 Recorded in Sir G Grey and C O Davis Maori Mementos (Williamson \& Wilson, Auckland, 1855) 21.

52 E Best "Maori Forest Lore" (1909) 42 Transactions of the New Zealand Institute, 433. 
the taonga was exchanged to the original owner ${ }^{53}$ of the taonga. Failure to do so would mean that "serious evil would befall" that person and they might even $\mathrm{die}^{54}$.

Kaeppler ${ }^{55}$ states that "the spiritual dimensions of the taonga - wairua (spirituality) and mana (authority) are the qualities that give them life for Maori people". For example, rivers are seen to have a spirit, spirituality and mana ${ }^{56}$. The Mohaka River is seen as "spiritual in all things" 57 . Mead notes that it is the spirit of the taonga (which he refers to as taha wairua) that is the major difference between "artifact" and "taonga". He goes on to relate this spirit to the way that taonga are passed from generation to generation; "One of the reasons why there is a high spiritual aspect to some taonga is because they represent an ancestor who is related by whakapapa (genealogy) to a group of descendants" ${ }^{\prime \prime}$.

Many stories support the idea that taonga have a spirit. Mead" states that "many people who visited the Te Maori exhibition said that they could feel the spiritual force of the taonga". The fact that taonga have a spirit or are affected by tapu is also alluded to in the story of two carvings that were brought to the Museum in Wellington from a burial site. The journey from the home of the carvings to the museum was filled with unexplained accidents. First, the train in which the carvings were travelling was derailed, and then the storeroom where the carvings were kept caught fire. In this type of case, the tapu must be lifted or cleared so that people can interact with the taonga safely, and a church service may

53 The giver of the gift. Mauss comments that the hau or spirit of the taonga may force people to do this. The hau may pursue people who steal taonga.

54 See Best above $\mathbf{n} 52$.

55 See Kaeppler (quoting Mead) above n 18, 15.

56 See Mohaka River Report n 6, 13.

In commenting on an early draft of this paper Dr GP Barton QC wrote:

"On reading the sentence to which note 56 refers, I was vividly reminded of an afternoon in Taumarunui 35 years or so ago. I had gone up to brief Titi Tihu, described in the court papers as "an aboriginal Native" in the litigation known as In re the bed of the Wanganui River [1962] NZLR 600, CA. I had spent some hours with Titi Tihu in one of the small rooms in the solicitors office in Taumarunui where I had gone to work for some weeks. As Titi Tihu was describing to me the way in which Maori thought of the Wanganui River, it became obvious that he was starting to become very emotionally worked up. He asked if I would excuse him. He said that he wanted to go away for half an hour or so. When he came back, it was apparent that he had recently been in water. He told me, almost shyly, that he had bathed in the Wanganui. He felt that he needed to get right into the spirit of the river. Clearly, for Titi Tihu the Wanganui had "spirit, spirituality and mana".

57 See Mohaka River Report above n 6, 18-19.

58 See Mead above $n$ 6, 166. "For the living relatives the taonga is more than a representation of their ancestor; the figure is their ancestor and woe betide anyone who acts indifferently to their tipuna (ancestor)".

59 See Mead above n 6, 166. 
be held "to control the awesome powers of the ancestors" whom the taonga represents ${ }^{60}$. It appears however that some taonga have a greater spirit than others and this depends on the person to whom they belonged, whether they are associated with death, whether their history or whakapapa is known, and factors such as their size $\mathrm{e}^{61}$.

A taonga is. It exists. It has a life-force, its own vitality ${ }^{62}$. This being is not only vital and vibrant but also has a spiritual emanation ${ }^{63}$ which controls the life of the taonga and affects all associated with ${ }^{6}{ }^{64}$. It is this that Tamati Ranapiri of the Ngati-Raukawa described to Elsdon Best, and it is of this that Mauss spoke in his famous essay The Gift ${ }^{65}$. The same point is developed in different contexts in the recent papers by $\mathrm{O}^{\prime}$ Connor ${ }^{66}$.

On this evidence alone it would appear that in English terms a taonga can have a personality and may be regarded as a person at least for certain purposes. If a Common Law court were to apply Maori law in the context of the exercise of a conflict of laws

60 See Mead above n 6, 167.

61 See Mead above n 6, 167-168.

62 Mauri.

63 Hau.

64 Best (in Spiritual and Mental Concepts of the Maori (Government Print, New Zealand, 1986), see pp. 29-30, 34, and 42) states that "the hau of a person, of land, of forests, etc, ... is an intangible quality", and translates the term hau as a "vital essence, ..., or active life-principle". He states that the 'hau of man' can be defined as "personality plus vital power". The hau is closely related to the mauri. The mauri is a "life principle" and some authors (Eg Tregear quoted by Best at p29) have translated it as "the soul". Best preferred to translate mauri as "the activity that moves within us".

The mauri of a taonga is referred to in the Report of the Waitangi Tribunal on the Manukau Claim (Wai-8) (Department of Justice, Wellington, 1985) 70:

3. 'Taonga' means more than objects of tangible value. A river may be a taonga as a valuable resource. Its 'mauri' or 'life-force' is another taonga. We accept the contention of Counsel for the claimants that the mauri of the Waikato River is a taonga of the Waikato tribes. The mauri of the Manukau Harbour is another taonga.

4. The guarantee of possession entails a guarantee of the authority to control that is to say, of rangatiratanga and mana.

5. Both 'fisheries' and 'taonga' inherently denote not simply the marine biota but the associated marine habitat, the waters, reefs and beds.

65 See Mauss above n8, and Best above $n 52$ at 439 . The use of language is reminiscent of Lord Shaw in the Mullick Case (see below n 79).

66 "The Passage from Magic to Folklore: Death, Magic and Mana Maori in Aotearoa (New Zealand)" in Magie et Fantastique dans le Pacifique (Université Française du Pacifique, Tahiti, 1993); and M O'Connor "Honour the Treaty? Property right and symbolic exchange" (1990) 1 Society and Culture: Economic Perspectives: Proceedings of the Sesquicentennial Conference of the NZ Association of Economists (NZ Association of Economists Incorporated, Wellington, 1990) Vol. 1, 138. 
jurisdiction, it could be expected to recognise important taonga as legal persons and accordingly as the bearers of the rights and duties which attach at Common Law.

\section{The common law}

In European legal culture conceptualisation is concerned primarily with two matters persons and things. Persons alone are the subject of rights and duties and have the recognition of law for the enforcement of these rights and duties as such ${ }^{67}$. Property exists principally as a reflection of the relationships of persons to things and of their rights and obligations in respect of things, be they movable, immovable, tangible or intangible.

Typically, the Common Law identifies persons with natural persons, that is to say human beings, and with groups of persons, whether natural or artificial ${ }^{68}$. Property is seen as inert, in the sense that its division, use distribution, or destruction are not seen as matters requiring the advice or consent of the property, and as lacking the inherent vitality to influence people or its own existence. An advantage of property is that usually it outlasts the life of the natural person who owns it. The creation of the corporation sole is an example of human endeavour to emulate property in this respect.

The concept of trust, a unique feature of the Common Law, produces some consequences not unlike those of the grant of personality: A trust provides continuity of purpose beyond the limit of a human life, and the property the subject of the trust does, through the trust purposes, exert strong influences on those involved with it. Conceptually, however, even then the law focuses on persons and in particular on those who own the trust property. If a trust is incorporated it is typically the trust board which is incorporated and not the trust property ${ }^{69}$. Those who own the property are the trustees and the beneficiaries. They own and control property. The property does not exist with its own rights and the power to control others. A person may say "I am my own person"; trust property must say "I am owned by persons".

These are the common patterns. They are not exclusive of other possibilities - property may have personality and human beings may be property ${ }^{70}$.

67 Background data on personality in European law may be found in W Friedmann Legal Theory (3ed, Stevens, London, 1953) 183-186, 396-412, Salmond on Jurisprudence (11ed, Sweet and Maxwell, London, 1957) Ch. 15, Dias \& Hughes Jurisprudence (Butterworths, London, 1957) Ch. 10.

69 See eg Charitable Trusts Act 1957, s 7.

70 And human beings may have no personality eg in English law - outlawry see W S Holdsworth A History of English Law (3 ed, Methuen \& Co Ltd, London, 1923) vol III, pp 604-607; in French law - civil death (art 22, Code Civil 1804). 
The techniques of the law are general in their use. Fictions are the basic tool, and in identifying the subjects of law the law may confer or withhold personality from living creatures, inanimate things, land, or ideas, with equal facility ${ }^{71}$ : Slaves have typically been treated as property ${ }^{72}$; the state is the Crown. The Crown has had attributed to it personality and has thence come to represent the state as a corporation sole ${ }^{73}$. The French law with its fondation ${ }^{74}$ and the German law with the Stiftung ${ }^{75}$, both provide examples of attributing legal personality to property ${ }^{76}$.

How a person, and particularly a person who is not a human being, interacts with property and other subjects of law is easily arranged. The paradigm is a human being of full

71 See generally Salmond on Jurisprudence (Sweet and Maxwell, London, 1966) 72, and Walker Oxford Companion to Law (OUP, 1980) 951 "Personality".

In Islam a typical dedication of property in perpetuity for charitable purposes (waqf) runs: "And whereas with the object of attaining nearness to God and reward in the next world and in consideration of the desire to approach God ... I hereby ... transfer and make waqf of [designated property] as a pious donation to God". God is the person to whom the gift is made.

By way of comparison see Maitland "The Corporation Sole" (1900) 16 LQR 335 where, at 346 in discussing a gift of land to God and the Church of Saint Peter of Westminster, he said: "We observe that God and St Peter are impracticable feoffees".

72 See generally A Szakats "Slavery as a social and economic institution in antiquity with special reference to Roman Law" (1975) Prudentia Vol VII No. 1, 33-45; for a more recent example see Sala-Molins Le Code Noir (PUF, Paris, 1987) - article 44 of the Code Noir of 1685 (in force till 1848) settled the matter "Slaves are chattels ..." ie, not land.

73 The locus classicus is Calvin's Case (1608) 2 State Trials at 624 . There, as in the case of the ecclesiastical corporations, the emphasis is on the human being. This however does not correspond exactly with 20th century usage and Commonwealth developments nor explain the synecdoche.

For a contemporary New Zealand discussion see P A Joseph "The Crown as a legal concept (I)" [1993] NZLJ 126.

74 The reference is here to the public use foundation - la fondation d'utilité publique. The grant of personality to property in these cases is government controlled. The personality flows from approval of the establishment of the fondation by the Conseil d'Etat. Such grants are made only for matters of significance and of proven viability.

75 Articles 80-88 BGB. Under German law legal personality may be granted to a rechstfähigen Stiftung or foundation. The foundation is established by an act of foundation which must specify the purpose and property of the foundation, and the grant of Federal or State authorisation. Representation and performing the tasks of the foundation is conducted by a Board (Vorstand). See for further detail, Palandt Burgerliches Gesetzbuch (27 edition, CH Beck'sche Verlagsbuchhandlung, München, 1968) pages 41-44; Staudingers Kommentar zum BGB Volume 1 (11 edition, J Schweißer Verlag, Berlin, 1957) pages 367-401.

The existence and status of the Stiftung was acknowledged in the Common Law in the series of English cases which culminated in the House of Lords' decision in Carl-Zeiss Stiftung v Rayner \& Keeler Ltd (No 2) [1967] 2 AC 853.

76 Generally on the French and German practices see de Wulf The Trust and Corresponding Institutions in the Civil Law (Bruylant, Bruxelles, 1965) 156, and Ryan An Introduction to the Civil Law (Law Book Co, Sydney, 1962) 235 and following. 
age and capacity and his or her agents. There are however natural persons who do not easily interact with the rest of the world ${ }^{77}$, and in all of these cases the law provides for the interaction with other persons and with property through a committee, a guardian, administrator or trustee, and in the same way the law has enabled artificial legal persons to interact with other members of the community - associations, companies, co-operatives, trade unions and so on which are incorporated, act through directors or boards of management. This model is followed for property which has personality: The Crown, fondations, and Stiftungen all act through managers who involve or are natural human persons.

The potentiality of the model could hardly be more tellingly stated than in the long line of Indian cases relating to Hindu temples and idols. One such case is the decision of the Supreme Court of India in Jogenda Nath $\mathrm{v}$ Income Tax Commissioner ${ }^{78}$ where the question was whether a Hindu deity could be treated as a unit of assessment for income tax purposes. The court surveyed Indian law and commented on Roman law conceptions of personality and the English trust. The conclusion was that the Hindu deity could be treated as a unit of assessment: "It is well established by high authorities that a Hindu idol is a juristic person in whom the dedicated property vests". Among the high authorities cited was the advice of the Privy Council given by Lord Shaw in Pramatha Nath Mullick v Pradyumna Kumar Mullick ${ }^{79}$. That case concerned three family idols: the household deity, the deity's consort, and a sacred stone. It was stated, inter alia -

One of the questions emerging at this point, is as to the nature of such an idol, and the services due thereto. A Hindu idol is, according to long established authority, founded upon the religious customs of the Hindus, and the recognition thereof by Courts of law, a "juristic entity." It has a juridical status with the power of suing and being sued. Its interests are attended to by the person who has the deity in his charge and who is in law its manager with all the powers which would, in such circumstances, on analogy, be given to the manager of the estate of an infant heir. It is unnecessary to quote the authorities; for this doctrine, thus simply stated, is firmly established.

...

77 Such as infants, and the mentally ill. Women and spouses have at various times also been held to lack full capacity to exercise their personality in their own right.

78 AIR 1969 SC 1089, 1090.

79 (1925) LR 52 Indian Appeals 245. A recent decision of the English Court of Appeal on a similar point is Bumper Development Corp Ltd v Commissioner of Police [1991] 4 All ER 638. This case concerned a Hindu temple's claim to an idol. 
It is sufficient to state that the deity is, in short, conceived as a living being and is treated in the same way as the master of the house would be treated by his humble servant.

$\cdots$

It must be remembered ... that the duties of piety from the time of consecration of the idol are duties to something existing which, though symbolising the Divinity, has in the eye of the law a status as a separate persona. The position and rights of the deity must, in order to work this out both in regard to its preservation, its maintenance and the services to be performed, be in the charge of a human being.

$\cdots$

But an argument which would reduce a family idol to the position of a mere movable chattel is one to which the Board can give no support.

If, in the course of a proper and unassailable administration of the worship of the idol by the shebait, it be thought that a family idol should change its location the will of the idol itself, expressed through his guardian, must be given effect to.

Their Lordships are accordingly of opinion that it would be in the interests of all concerned that the idol should appear by a disinterested next friend appointed by the Court.

\section{Taonga as persons}

The conceptual possibility exists within the Common Law system to recognise and to attribute rights and duties to taonga by the grant of legal personality. How may this possibility be realised? The Common Law may recognise personality by prerogative grant from the Sovereign, by the effect of precedent, or by Parliamentary action. The grant of personality to other than human beings is typically, but not necessarily, coincident with incorporation. Incorporation is the usual pattern where there is a need to separate the new person from the groups who form it or to give the new person perpetual life.

There is no doubt the Common Law could recognise taonga as legal persons by its own incremental processes as part of the developing recognition of the role of Maori law within New Zealand. Certainly, the decision in Mullick raises the possibility that the personality of taonga could be recognised in the New Zealand courts ${ }^{80}$. It is necessary to recall, however, that Mullick was essentially a conflict of laws decision. The Privy Council's

80 The Privy Council's advice in Mullick has been noted in the New Zealand case of Huakina Development Trust $\mathbf{v}$ Waikato Valley Authority [1987] 2 NZLR 188, where Chilwell J termed it "interesting" (197). 
advice was a recognition of the status conferred on the idol by Hindu law and not a conferral of status by English law. New Zealand cases have, for the most part, shown a reluctance to admit the co-existence of alternative legal systems within New Zealand. Nevertheless, there are indications that recognition of Maori law is possible ${ }^{81}$. As Maori law is accorded increasing recognition, it is possible to envision the time when New Zealand courts might acknowledge the personality of taonga at Maori law. The taonga would then be recognised as the possessor of personality within New Zealand law in the same manner as if personality had been conferred by the law on a company or an incorporated society.

It is interesting to note the situation in some other Pacific jurisdictions. A recent Cook Islands constitutional amendment provides for the continued operation of Cook Islands customary law in the Cook Islands until extinguished by statute ${ }^{82}$ A comparable situation exists in Western Samoa where the preamble to the Constitution and recent statute acknowledge the importance in the Western Samoan context of customary law ${ }^{83}$.

Recognition of taonga as persons within New Zealand common law is possible, but such a process is likely to be slow unless it receives specific impetus from, for instance, a report of the Waitangi Tribunal which linked the ideas either in whole or in part, or by a piece of legislation which explicitly recognised attributes of personality from which the courts could generalise.

81 In this connection, see Te Runanganui o Te Ika Whenua Inc Society v Attorney-General [1994] 2 NZLR 20, 27, where the Court of Appeal states that "in recent years the Courts in various jurisdictions have increasingly recognised the justiciability of the claims of indigenous peoples - ... the New Zealand Courts in a line of cases in which it has been seen, not only that the Treaty of Waitangi has been acquiring some permeating influence in New Zealand law, but also that Treaty rights and Maori customary rights tend to be partly the same in content". Positive reference to Maori law has been made in decisions such as Public Trustee v Loasby (1908) 27 NZLR 801, In re Tatana (Unreported) A34/81 (18 November 1982), Re Adoption of A [1992] NZFLR 422; and most recently (and in passing) in Awa v Independent News Auckland Ltd (Unreported) 24 August 1994, Hamilton Registry CP 152/92. The Runanganui o Te Ika Whenua case also refers to the "fiduciary duty widely and increasingly recognised as falling on the colonising power" (24).

82 Constitution of the Cook Islands, Part IVB, "Custom", article 66A, as inserted by the Constitution Amendment (No 17) Act 1994-95 (Act No 36 of 1994-95). Subclause (3) provides that "Until such time as an Act otherwise provides, custom and usage shall have effect as part of the law of the Cook Islands, provided that this subclause shall not apply ... to the extent that it is inconsistent with a provision of this Constitution or of any enactment".

83 The preamble to the Constitution of the Independent State of Western Samoa 1960 provides that the Independent State of Western Samoa shall be "based on Christian principles and Samoan custom and tradition". The Village Fono Act 1990 explicitly recognises that Samoan custom is effective law in the villages: "Every Village Fono in the exercise of any power or authority shall exercise the same in accordance with the custom and usage of that village" (section 3(2)). 
The easiest way to grant personality in state law and one which is both explicit and clear, and runs the least risk of damage or translation ${ }^{84}$ is by Act of Parliament. Parliament has, by virtue of its supremacy, the possibility of creating personality instantly. It does this by Public or Private Act, and the suitability of one over the other could depend on the taonga in question.

The advantage of a Private Act would be the possibility of its private promotion. A Public Act is however notionally more all-embracing, and is recognised as general and of national impact and consequence. If the taonga is one of national interest, the appropriate Act would be a public general Act. In the case of matters arising from a Treaty claim a well formulated preamble or objects clause would be the best way to set out the particular context in which the statute has evolved and should operate.

The Act itself could be brief. In fact, the simpler the Act the more likely it would be to fulfil the purposes of its enactment. The taonga by its nature carries with it its essence. The sole purpose of an Act would be to declare that in the state law the particular taonga has legal personality. For that it should suffice to identify the taonga involved, to grant it legal personality, and to indicate how the taonga will in State law exercise its rights and perform its duties.

If Parliament later changed its mind and repealed an Act which granted personality at law to a taonga, the legal consequence in the Common Law would be that the taonga would cease to have the legal personality as created by the Act. In Maori law the taonga would still have its status under that law. However the law of the state at least would have lost a bridge to understanding, and the state would be back to the position of having to struggle with the difficulties inherent in regarding taonga simply as items of property.

Once recognised as a person, the critical question is then to address how the new legal entity should protect its interests and perform its duties. For this, it could be assisted by a statutorily established board of management or board of trustees (which may be incorporated or unincorporate) whose role would be to look to the interests of the legal person. Precisely what those interests were and the way in which they should be established in a given case would require advised drafting and reasonably clear identification of the interests of the taonga. Something in the nature of a purpose or objects clause would be needed in the founding document. The phrasing of that clause would dominate the activity of the board and provide authority and justification for its actions. Matters of detail relating to the board of trustees or board of management could be dealt with in a statutory schedule, by subordinate legislation, or administratively, using the great 
range of precedents on statutory bodies available to suggest different ways in which management matters could be settled.

Historically many groups may have interacted with a given taonga and had their daily lives and their interactions with others influenced by it. Where a taonga affected the lives of several different groups, they may all have participated in its management or stewardship. For such cases it would be possible to replicate the cultural model of interaction between interested groups and the taonga in the identification of the board of management or trustees by which the taonga would act.

The interaction of the taonga with other persons and with other interests would follow in accordance with the general principles of law and the legislation that impacts on all persons. In the event that there were specific statutory provisions which needed to be taken into account in the life of the taonga, those matters could be addressed in the usual way in any founding statute or by way of delegated legislation ${ }^{85}$.

\section{Conclusion}

Both Western European legal culture and Maori law provide special treatment for features of social or political life that are exceptional and worthy of special respect and protection. The recognition or grant of personality is an important way to acknowledge this special treatment. Personality is recognised in aspects of life that are out of the ordinary, whose meaningfulness is not limited to the natural life span of a single human being, and whose identity is worth maintaining. It may be inappropriate to negotiate about taonga in Western European legal terms; if it is appropriate to do so, or if doing so is unavoidable, then reference to the concept of personality may be helpful. The advantage of the use of personality is that the taonga would be regarded as different from property, that there would be legal recognition of the continuity of management, and that the focus would shift from humans and their interests to the character, attributes and spirit of the taonga. This shift of focus is important in that it would provide clear recognition by the state that something more than a simple object or geographical feature and competing humans is involved. The personality of the taonga would be made to transcend any human rivalries and any stark property analysis.

Article 2 of the Treaty of Waitangi confirms and guarantees to Maori specified and exclusive rights. These include the stewardship of taonga. It is submitted that the recognition or grant of personality to significant taonga would support these rights.

85 Or, eg by codes of practice. Further various formulas are used regularly by Parliament to exclude the operation of other statutes (Notwithstanding any other law ...), or for subordinating functions (Subject to sections --- of the --- Act ...), or for consistency with other law (eg in accordance with the principles of the Treaty of Waitangi). 


\section{La personnalité morale et le droit Maori}

Les interactions entre le droit Maori et les concepts juridiques européens qui sont en vigueur en Nouvelle Zélande ont au cours des dernières années donné lieu à des débats passionnés non exempts d'arrières pensées politiques. Plus récemment la discussion s'est centrée autour du traité de Waitangi et de l'action du tribunal de Waitangi. L'intérêt du public s'est surtout manifesté à l'égard du bien fondé des revendications foncières engagées sur la base du traité, les conséquences culturelles des revendications étant quant à elle laissées au second plan. Les considérations financières ont pris le pas sur les préoccupations d'ordre culturelles. Cet article a pour objet de tenter de recentrer le débat sur un aspect particulier du contenu des revendications de tous ordres, à savoir l'institution dite du "Taonga" et de proposer le recours aux principes du droit de la personnalité pour résoudre les difficultés qu'elle engendre.

Les rares articles du Traité de Waitangi ont servi, jusqu'à présent, de fondements aux rapports humains et sociaux dans une société marquée par deux composantes ethniques, de telle sorte que l'accent a été plus particulierement mis sur la reconnaissances des valeurs et du statut des Maoris dans un système à dominante culturelle européenne. Dès la mise en place du Tribunal de Waitangi en 1975, il est rapidement devenu patent que deux conceptions divergentes des cultures s'opposaient de manière fondamentale et rédhibitoires. Dés lors le législatif, l'exécutif tout comme le judiciaire n'ont eu de cesse de prendre en compte ce paramètre.

Dans ce contexte une de leur préoccupation a été d'accorder une pleine reconnaissance au concept de Taonga, tel qu'il est indiqué à l'article 2 du traite de Waitangi. En fait Taonga est un vocable à significations multiformes.

Trois traductions, aux conséquences différentes peuvent etre proposées. En premier lieu, il s'agira de la propriété, puis de toutes choses d'importante valeur, mais aussi toutes possessions inférant une forte connotation de pouvoir d'influence, y compris spirituelle. En l'état seront considérés comme Taonga, tous biens corporels ou incorporels à forte connotation artistique ou culturelle, les forets, les rivières, la langue, les coutumes, traditions, les chants rituels, les rites, la terre, les arbres, les armes, voire enfin le peuple maori dans son ensemble. Le concept du Taonga peut etre identifié dés lors qu'existe un lien spirituel entre le bien et le peuple maori et sa culture.

Une des caractéristiques du Taonga est qu'il est transmissible de génération en génération, chaque dévolution confortant la valeur et la force spirituelle qui s'y attachent. Facteur de rattachement de l'individu au groupe maori, il est à la fois le témoin de l'histoire du groupe, et de la relation personnelle de l'individu par rapport à un groupe déterminé. Comme l'a justement souligné Mead, tout aussi important est la possibilité pour le Taonga 
d'etre doté d'une personnalité distincte et de pouvoirs spirituels. Dans la conception maori, le Taonga a sa vie propre et une vitalité qui lui est propre.

Dans un autre ordre d'idées, la conception européenne du droit gravite autour de deux concepts: les personnes et les biens. La propriété n'existe qu'au regard des relations des individus envers les biens, des droits et obligations qui s'y attachent. La Common Law (exception faite toutefois de l'application du concept dit de "Corporation Sole" grâce auquel la notion de Couronne par exemple, trouve sa justification) ne conçoit que deux types de personnes morales à savoir l'etre humain et le groupement social à qui l'on a conféré artificiellement la personnalité morale. Le bien dont on est propriétaire est par définition un bien sans personnalité propre dont la division ou la destruction ne requièrent pas l'assentiment du dit bien.

Une exception cependant, le concept de trust, institution et fiction légale originale de la Common Law, qui présente quelques caractéristiques d'une personnalité autonome. On retrouve des concepts similaires dans le droit français avec la fondation et le droit allemand de la Stiftung. Chaque fois le bien est doté d'une personnalité qui lui est propre et qui est distincte des personnes physiques qui le gère.

L'analyse de l'ensemble de la jurisprudence des tribunaux Indiens relative aux temples et idoles permet d'établir sans équivoque que ces biens particuliers sont dotés d'une personnalité juridique qui leur est propre.

On voit donc que la Common Law n'est pas réfractaire à l'idée de conférer une personnalité distincte à des biens meubles et immeubles. Reste maintenant à savoir si le pas peut etre franchi pour le Taonga.

Si tel devait etre le cas deux possibilités s'offrirait alors: le recours à une reconnaissance par les tribunaux, ou une intervention législative. La première branche de l'alternative est parfaitement concevable et il existe déjà un précèdent (Jugement dans l'affaire Mullick rendu par le Privy Council) qui quand bien même il ne concernerait au premier chef que le droit international privé, n'en ouvrirait pas moins des perspectives sérieuses de reconnaissance dans le droit interne. Il convient cependant de noter que la reconnaissance judiciaire de la personnalité morale du Taonga risque d'etre longue sauf un impetus particulier émanant du tribunal de Waitangi. La seconde branche de l'alternative est quant à elle la plus séduisante et sans doute la plus facile. Que se soit par le recours à une loi de caractère civil ou de droit public, le législateur peut consacrer instantanément une reconnaissance pleine et entière de la personnalité morale Taonga. 